\title{
AÇões DE UM LICENCIANDO EM QUÍMICA EM SITUAÇÃO DE MICROENSINO SEGUIDA DE AUTOSCOPIA
}

\author{
ACTIONS OF A UNDERGRADUATE STUDENT IN CHEMISTRY IN A MICRO- \\ TEACHING SITUATION FOLLOWED BY AUTOSCOPY
}

DOI: 10.23926/RPD.2526-2149.2020.v5.n3.p1841-1864.id831

\section{Wilson Carvalho \\ Mestre em Ensino de \\ Ciências e Educação em \\ Matemática (UEL) \\ Professor da Secretaria do \\ Estado do Paraná (SEED) \\ carvalhowilson87@gmail.co \\ $\underline{\mathrm{m}}$ \\ Enio de Lorena \\ Stanzani \\ Doutor em Educação para a \\ Ciência (Unesp) \\ Professor da Universidade \\ Tecnológica Federal do \\ Paraná (UTFPR) \\ enio.stanzani@gmail.com}

\section{Marinez Meneghello \\ Passos}

Doutora em Educação para a

Ciência (Unesp)

Professora Sênior da

Universidade Estadual de

Londrina (UEL)

Programa de Pós-Graduação

em Ensino de Ciência e

Educação Matemática (UEL)

marinezmp@sercomtel.com.

br

\section{Álvaro Lorencini \\ Júnior}

Doutorado em Educação

(USP)

Professor da Universidade

Estadual de Londrina (UEL)

Programa de Pós-Graduação

em Ensino de Ciências e

Educação Matemática (UEL)

lorencinijunior@gmail.com
Resumo: Neste artigo apresentamos os resultados de uma pesquisa que procurou analisar a perspectiva de ensino e aprendizado do licenciando em Química e os efeitos da intervenção do professor formador nas ações do futuro professor em aulas simuladas. Para o levantamento dos dados, todas as atividades realizadas pelo licenciando, provenientes das regências em sala de aula, mediante situações de microensino seguidas de análise a posteriori, foram gravadas, sendo o procedimento denominado de autoscopia. Organizamos as transcrições das aulas e as interpretamos, segundo os procedimentos da Análise Textual Discursiva, assumindo, para a identificação das ações, um conjunto de categorias a priori e um conjunto de subcategorias emergentes. Esse movimento permitiu identificarmos alterações nas ações, observando variações da quantidade de ações relacionadas a cada uma das subcategorias, o que nos leva a defender a relevância da realização dos procedimentos de autoscopia e microensino como possibilidade de alterações/mudanças na perspectiva de ensino e nas ações do licenciando.

Palavras-Chave: Licenciatura em Química. Ações Docentes. Estágio Supervisionado. Microensino. Autoscopia.

\begin{abstract}
In this article we present the results of a research that analyzes the perspective of teaching the learning of the Chemistry degree and the effects of the intervention of the teacher actions of a future chemistry teacher in simulated classes. For data collection, all activities carried out by the licensee, from the regency in the classroom, through micro-teaching situations followed by a posterior analysis of the recorded classes, a procedure called autoscopy. We organize as transcriptions of the classes and interpret such transcriptions, according to the procedures of the Discursive Textual Analysis, assuming, for the identification of the actions, a set of a priori categories and a set of emerging subcategories. The mandatory procedure identifies changes in actions, we observe variations in the number of actions related to each of these subcategories, which leads us to an advocate of performing autoscopies and micro-teaching as a possibility of alteration / changes in the teaching perspective and in the licensee's actions.
\end{abstract}

Keywords: Chemistry Degree. Teacher Actions. Supervised Internship. Micro-teaching. Autoscopy. 


\section{INTRODUÇÃO}

É fato que as influências do ensino tradicional e conservador, ainda hoje, estão presentes na Educação Básica e no Ensino Superior; por conseguinte, as ações docentes mostram-se permeadas por um pensamento newtoniano-cartesiano que fragmenta e isola as disciplinas. Esse movimento torna os professores reprodutores de conhecimento e os impulsiona para uma prática pedagógica mecânica em sala de aula. Perante esse cenário o aluno deve permanecer em silêncio, prestar atenção, escrever, decorar e reproduzir o conteúdo proposto (BEHRENS, 1999).

Ao voltarmos nossos olhares para o Ensino Superior, deparamo-nos com um agravante: essa instituição dominada por uma forte tradição é a mesma responsável por formar os futuros professores. Nesse processo formativo tem-se a disciplina de estágio supervisionado que oportuniza o ambiente para que esse futuro professor desenvolva sua técnica e inicie a experiência profissional. Caso essa disciplina de estágio permita lacunas na formação profissional, o licenciando pode preencher tais lacunas com a reprodução de modelos considerados por ele bons ou ideais, conforme sua experiência estudantil. Diante da perspectiva da imitação, o modelo criado de bom professor é subjetivo e depende de uma interpretação. A limitação crítica para a criação de um modelo profissional de professor permite prevalência do modelo dominante, assim a tradição resiste, conservando seus hábitos, ideias e valores (PIMENTA; LIMA, 2017).

Inspirados por Pimenta e Lima (2017), que destacam o estágio supervisionado como campo de conhecimento para a pesquisa e atribuem a ele significativo papel no auxílio da construção do profissional docente, um ambiente de estágio que desperte para a reflexão nas ações pode estimular novos modelos de ensino. Para direcionar essas significações, precisamos antes analisar as ações do licenciando sem experiências na prática do ofício, procurando indícios que possam revelar sua perspectiva de ensino. Após indicativos das concepções do licenciando, o professor formador, pautado em pesquisas com viés crítico e reflexivo, pode nortear suas ações intervencionistas.

Considerando o exposto anteriormente, assumimos, por etapas, para as intervenções que podem culminar em mudanças nas ações do licenciando, um procedimento conhecido como 'microensino aliado com autoscopia'. Imersos neste contexto, nosso objetivo foi o de analisar as ações do estudante da disciplina de estágio durante o processo de intervenção idealizado pelo professor formador, com o intuito de identificar possíveis mudanças nas perspectivas de ensino 
do licenciando. Os resultados desse processo formativo e interventivo é o que trazemos neste artigo.

Para elucidar a trajetória investigativa, estruturamos o artigo da seguinte forma: uma seção em que discorremos a respeito de nossas compreensões sobre o processo formativo e esclarecimentos a respeito da proposta de microensino integrada com a autoscopia; na sequência, indicamos o que compreendemos por ação e o referencial que assumimos e que nos apresenta as categorias a priori; na continuidade, expomos alguns destaques relativos aos procedimentos metodológicos, os quais ancoraram o processo de emergência de subcategorias, que julgamos representativas da situação analisada; por fim, apresentamos os dados organizados e interpretados, e nossas considerações conclusivas.

\section{REFERENCIAIS NORTEADORES DA INVESTIGAÇÃO}

As diferentes formas de conceber as práticas educativas podem moldar as ações do futuro professor, suas crenças e suas concepções sobre o que é ensinar e o que é aprender. Além disso, o contato social na vida acadêmica do licenciando pode influenciar na incorporação ideológica do que é ser professor, e a ideologia dominante direciona sua prática educativa, que pode ser acomodada, de forma resumida, em três perspectivas ideológicas, incorporadas no ensino que orienta a formação acadêmica há décadas (em diversos cursos): Perspectiva acadêmica; Perspectiva técnica; Perspectiva prática (com foco na prática reflexiva), como nos apresentam Sacristán e Gómez (1998). No Quadro 1 descrevemos, de forma adaptada do texto original, as três perspectivas.

Quadro 1 - Três perspectivas norteadoras de formação de professores

\begin{tabular}{|c|l|}
\hline Perspectivas & \multicolumn{1}{c|}{ Características gerais } \\
\hline \multirow{5}{*}{ Acadêmica } & $\begin{array}{l}\text { Realça o ensino como um processo de transmissão de conhecimento acumulado pela } \\
\text { humanidade; o docente é um especialista na disciplina que leciona; a formação didática e } \\
\text { formação pedagógica não são importantes nessa perspectiva; não é possível identificar a } \\
\text { diferença de saber e saber ensinar; o professor transmite o conhecimento de forma clara e } \\
\text { ordenada, considerando a sala de aula um ambiente homogêneo; o conhecimento da } \\
\text { humanidade é visto como histórico e temporal. Diante desse enfoque o professor eficiente é } \\
\text { aquele que domina a técnica de transmissão, ou aplica técnicas produzidas por pesquisadores. }\end{array}$ \\
\hline Técnica & $\begin{array}{l}\text { O docente aplica técnicas de ensino subordinado aos investigadores que trabalham para } \\
\text { resolução de problemas, o que Schön (2000) denomina de racionalidade técnica; o professor } \\
\text { pode ser treinado para executar um conjunto de processo para atingir um produto final e acabado } \\
\text { com auxílio de tecnologias educacionais; o professor domina a técnica de transmissão realizada } \\
\text { por acadêmicos e a executa. Apenas isso garante o aprendizado dos alunos. São analisados casos } \\
\text { isolados de falhas no aprendizado, o qual é um aprendizado mecânico e linear, sem levar em } \\
\text { conta o contexto cultural. }\end{array}$ \\
\hline Prática & $\begin{array}{l}\text { Nesta perspectiva o ensino é uma atividade complexa, singular e heterogênea, o contexto de } \\
\text { ensino no ambiente escolar é carregado por conflitos, múltiplos fatores e condições adversas. O } \\
\text { ambiente escolar é visto como diversificado e os conflitos não podem ser resolvidos com a } \\
\text { aplicação de uma técnica ou um procedimento único. O professor é considerado um artesão, }\end{array}$ \\
\hline
\end{tabular}




\begin{tabular}{|l|l|}
\hline artista ou um profissional capaz de criar estratégias e, por experiências anteriores, tem a \\
capacidade de enfrentar situações únicas, ambíguas, conflitantes e incertas. A formação do \\
professor com perspectiva prática, considera o ambiente de sala de aula potencialmente frutífero \\
para o desenvolvimento do professor. A investigação e a reflexão na prática são realizadas de \\
forma sistemática com auxílio de referenciais teóricos que auxiliam e direcionam suas ações, \\
procurando por meio das ações a construção do ensino e do aprendizado de cada aluno. \\
Considera o ambiente escolar heterogêneo e o conhecimento da humanidade construído pela \\
sociedade.
\end{tabular}

Fonte: Adaptado de Sacristán e Gómez (1998, p.356-373).

Cabe informar que esse balizamento teórico, assim como os que trazemos a seguir, sustentaram a interpretação dos dados coletados e nossa condução analítica. Por tal motivo, julgamos importante apresentá-los nesta seção.

Conforme Tardif (2014) e Pozo (2002) indicam, a imersão cultural no ambiente escolar do licenciando ocorre nos primeiros anos de sua vida. De forma não reflexiva o futuro professor idealiza o que é ser professor, o que é ser aluno, o que é ensinar e aprender, ainda quando criança. A observação e a repetição de modelos, que durante o período como aluno observou e definiu como sendo ideal, um conjunto de crenças, os conhecimentos, as atitudes e os valores são incorporados com grande convicção e direcionam sua prática profissional. A situação exposta neste parágrafo é mencionada e denominada de formas diferentes por outros autores. A seguir expomos aqueles que nos chamaram a atenção.

Aprendizado por modelagem citado por Bandura (1977 apud POZO, 2002): é possível de ser identificado em crianças que copiam os comportamentos dos adultos e por meio desses recursos direcionam o comportamento social, repetindo todos os comportamentos que observam. Quando a criança atinge a vida adulta e escolhe por lecionar, percebe-se que suas ações em sala de aula são uma cópia da atuação dos seus professores.

Para Maldaner (2006) a observação de professores atuantes pode nos remeter: ao momento em que o futuro professor direciona seu comportamento profissional observando professores em ação; à conivência no papel de aluno que induzirá o comportamento do futuro professor; ao período em que ele era um aluno e que direcionará seu jeito de ser e de agir no exercício da sua profissão; a um conjunto de crenças enraizadas e forjadas no cotidiano que dificulta as modificações que elevariam o aproveitamento e a inovação didática.

Tais colocações nos levam a compreender que o processo de formação tem como objetivo apresentar novas perspectivas. Para isso, o professor formador precisa desvincular os saberes pré-profissionais do futuro professor, os quais foram moldados na imersão cultural, induzindo a práticas não reflexivas. É importante tornar o licenciando consciente da 
complexidade envolvida no processo de ensino e de aprendizagem, rompendo a visão simplista de transmissão de conhecimento, assim como nos indicam Carvalho e Gil-Pérez (2011).

Assumimos também o que nos traz Schön (2000), quando afirma que o momento da prática profissional é concebido como uma oportunidade de reflexão na ação, que leva a pessoa a problematizar, analisar e construir conhecimento. A prática profissional possibilita a criação de um repertório de experiências que poderá ajudar a entender as transformações sociais e educacionais, permitindo refletir acerca de velhas concepções e preparando o professor para múltiplas situações a serem vivenciadas na escola.

Nessa mesma linha de raciocínio temos Alarcão (1996), considerando que:

A formação profissional deve facultar ao formando a oportunidade de praticar "sob a orientação de um profissional" que seja o "seu treinador, companheiro e conselheiro", uma pessoa competente que o ajude a desvendar gradualmente a realidade profissional e o leve a "aprender a fazer fazendo". (ALARCÃO, 1996, p.13, assinalamentos da autora).

Pensando na formação profissional direcionamos nossas atenções para o estágio inicial docente, momento que oportuniza, ao futuro professor, o contato com referenciais teóricos e metodológicos, que é intermediado por um professor formador sendo capaz de "[...] desvendar gradualmente a realidade profissional [...]" (ALARCÃO, 1996 p.13). Acomodamos, ainda, junto a esse movimento, dando ênfase ao desenvolvimento do professor reflexivo um profissional crítico, mediador no processo de aprendizado, consciente das ações pedagógicas e capaz de construir conhecimentos ao pesquisar sua própria ação.

\subsection{AUTOSCOPIA VINCULADA AO PROCEDIMENTO DE MICROENSINO}

O procedimento técnico denominado autoscopia (SADALLA; LAROCCA, 2004) tem como objetivo a utilização de videogravação do ambiente (sala de aula), em que diversas ações ocorrem simultaneamente com sujeitos envolvidos em uma determinada circunstância.

Basicamente dois procedimentos direcionam o processo de pesquisa por autoscopia: primeiro realiza-se as gravações das imagens, e no segundo momento faz-se a análise das imagens. Tal processo analítico ocorre por meio do estudo e da aceitação de referenciais teóricos que servem como guias. Em nosso caso, além dos referenciais adotados pelo professor formador, que norteavam os licenciandos e, por isso, puderam elucidar as apurações das ações desenvolvidas durante a realização das aulas (situações de microensino ${ }^{1}$ ) que foram gravadas em vídeo e áudio, assumimos também que a autoscopia possibilita uma “[...] tomada de

\footnotetext{
${ }^{1}$ Fernández (2010) define microensino como ambiente de simulação de aula com menor complexidade e que o professor possa vivenciar a prática docente com instruções norteadoras.
} 
consciência das atitudes e comportamentos dos professores e dos alunos em sala de aula nas diversas atividades de ensino" (SADALLA; LAROCCA, 2004, p.2).

O processo interpretativo da autoscopia é delineado por aspectos predominantemente qualitativos, no ambiente natural em que as imagens são gravadas. O pesquisador procura captar o maior número de situações possíveis, diante do cotidiano do ambiente escolar registrado. $\mathrm{O}$ investigador valoriza todo o processo, não apenas o produto final. A pesquisa é realizada de forma indutiva em que o observador procura captar as perspectivas dos participantes, tendo em vista os referenciais teóricos que norteiam sua pesquisa (LÜDKE; ANDRÉ, 1986, p.12).

Considerando as interferências e a complexidade do ambiente educacional, o conjunto de pressupostos peculiares da metodologia qualitativa proporcionou seu crescente uso nas últimas décadas, diante da pluralização da sociedade moderna e a velocidade de transformação social. Cabe destacar que é fundamental que os estudos se limitem a um determinado espaço, tempo e situação (FLICK, 2009), elementos esses que vêm ao encontro da utilização de autoscopias, sustentando nossa escolha investigativa.

Tendo exposto de forma resumida o que consideramos por autoscopia, trazemos agora informações a respeito do que adotamos por microensino e sua vinculação com a realização de autoscopias. O procedimento de microensino, conforme Fernández (2010), é uma simulação de aula, em que o licenciando assume o papel de professor, porém o tempo de aula é reduzido (em turno de 30 minutos no máximo), com um número de alunos reduzido, os quais, em nosso contexto investigativo, formam os próprios colegas, cinco licenciandos do curso, pois a turma era composta por 6 acadêmicos.

O microensino sistematiza a análise por meio de três momentos: no primeiro momento, o Ensino, o futuro professor ensina para um número reduzido de alunos; no segundo momento, o Feedback, o professor formador analisa o vídeo destacando pontos positivos e negativos do procedimento desenvolvido no decorrer da aula; no terceiro momento, o Reensino, o licenciando novamente leciona para a mesma turma, procurando melhorias nas dificuldades e limitações, conforme orientações do professor formador (FERNÁNDEZ, 2010).

Pautados nessas orientações expostas, e considerando o "Esquema de integração de fase microensino e autoscopia" de Arrigo, Lorencini Júnior e Broietti (2017, p.11), exposto na Figura 1, sistematizamos nossos procedimentos metodológicos descritos na próxima seção. 
Figura 1 - Esquema de integração de fase microensino e autoscopia

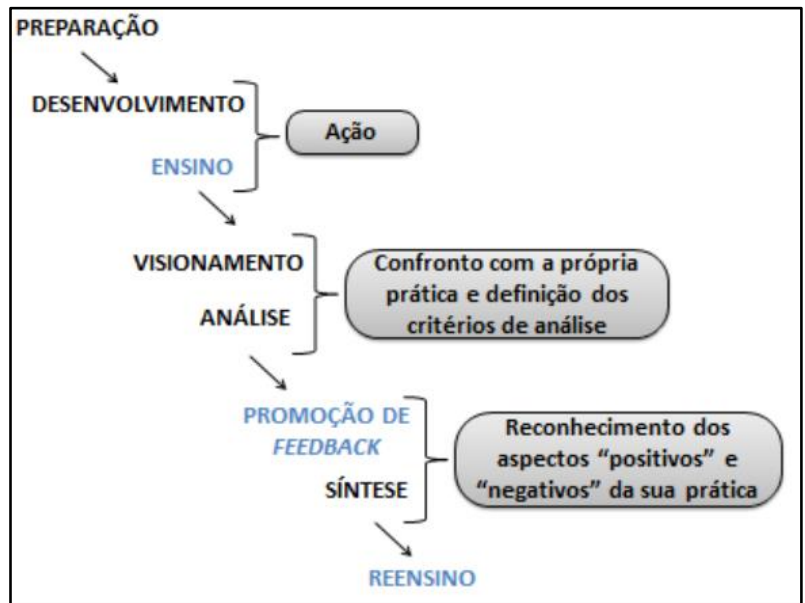

Fonte: Arrigo, Lorencini Júnior e Broietti (2017, p.11)

Ressaltamos que esta estrutura apresentada anteriormente, segundo os autores de origem, não segue uma forma rígida de execução, pois há casos em que a instituição, onde ocorre o desenvolvimento do microensino integrado com a autoscopia, remodela essa ordenação, conforme os recursos físicos e humanos disponíveis no ambiente em que o processo acontece.

\section{Procedimentos Metodológicos: ALgUnS ESCLARECIMENTOS}

Para o desenvolvimento desta investigação, as aulas ocorridas durante todo o semestre, em um curso de Licenciatura em Química de uma Universidade Federal do estado do Paraná, foram gravadas em áudio e vídeo e, posteriormente, transcritas. O curso pesquisado tinha, naquela ocasião, a duração de 4 anos, e a disciplina de Estágio Supervisionado 2 ocorria no $6^{\circ}$ semestre. A turma acompanhada nesta investigação possuía 6 estudantes, e neste momento trazemos os dados relativos a um deles, o qual julgamos representativo dos demais. Todos eles eram bolsistas do Programa Institucional de Bolsas de Iniciação à Docência (PIBID), sem experiências profissionais anteriores no magistério e com média de 21 anos. Tal recorte nos dados deu-se em função da quantidade excessiva de informações que teríamos se os 6 estudantes fossem considerados. Todavia, a completude dessas análises e de seus resultados pode ser acessada em Carvalho (2019). A falta de experiência profissional possibilita identificar um conjunto de saberes pré-profissional, construído no período em que o licenciando ainda era um aluno, conceitos e ideias do que é ser um profissional professor, moldado na raiz cultural.

Segundo Tardif (2014), o futuro professor interioriza:

O ensino [...] certo número de conhecimentos, de competências, de crenças e de valores etc., aos quais estruturam suas personalidades e relações com os outros 
(especialmente com as crianças) e são reatualizados e reutilizados de maneira não reflexiva, mas com grande convicção, na prática do seu ofício. (TARDIF, 2014, p.72).

Nos últimos anos houve um aumento nos estudos relacionados ao saberes préprofissionais, porém as pesquisas ainda permanecem insuficientes, segundo nos indica Tardif (2014). Considerando tal assinalamento, nosso objetivo investigativo foi o de colaborar com pesquisas no território "desconhecido" dos saberes pré-profissionais, que podem moldar as práticas educativas e direcionar as ações.

Inspirado nos procedimentos relativos ao microensino e à autoscopia (FERNÁNDEZ, 2010; SADALLA; LAROCCA, 2004), assistimos videogravação das aulas ministradas pelos estudantes, contudo, aqui focamos somente nas aulas de um deles, conforme justificado anteriormente, e realizamos o levantamento das ações observadas, tendo por pauta o que nos apresenta Andrade (2016).

Na ocasião de seu desenvolvimento investigativo, Andrade (2016) concluiu que as ações de diversos professores investigados poderiam ser organizadas em quatro categorias: Burocrático-administrativa; Espera; Explica; Escreve, que assumimos por categorias a priori, em nosso processo interpretativo.

No Quadro 2 trazemos essas categorias, seguidas de uma descrição de quais são as ações que consideramos em cada uma delas para sustentar as escolhas analíticas realizadas. Cabe informar que essas descrições foram adaptadas do que nos apresenta Andrade (2016) e do que temos em Carvalho (2019), com mais detalhes e justificações.

Quadro 2 - Categorias de ação e descrição das ações

\begin{tabular}{|c|c|}
\hline $\begin{array}{c}\text { Categorias de } \\
\text { ação }\end{array}$ & Descrição resumida das ações \\
\hline $\begin{array}{l}\text { Burocrático- } \\
\text { administrativa }\end{array}$ & $\begin{array}{l}\text { Ações que incluíam tempo utilizado para chegar ou sair da sala de aula; tempo esperando } \\
\text { pelos alunos para iniciar a aula; tempo em que, enquanto espera pelos alunos para iniciar a } \\
\text { aula, conversa com os que estão chegando; realização de chamada; tempo utilizado dando } \\
\text { bronca a fim de conseguir realizar a chamada; intervenção para a pedagoga dar recado; } \\
\text { registro de ocorrência devido a alguma desordem em sala de aula; conversa com alunos } \\
\text { antes de iniciar a aula; anotações no livro de chamada; conversa com a pesquisadora e } \\
\text { intervenção de outras pessoas na sala de aula. }\end{array}$ \\
\hline Explica & $\begin{array}{l}\text { Ações que o professor realiza quando está explicando e interrompe a explicação para } \\
\text { esperar pelo silêncio dos alunos; ação em que o professor está explicando o conteúdo ou o } \\
\text { exercício e o aluno está, ou não, participando; ação em que o professor está explicando e } \\
\text { interrompe a explicação para chamar a atenção de um aluno ou de alunos que estão } \\
\text { atrapalhando de alguma forma o andamento da explicação; ação em que o professor está } \\
\text { explicando e resolvendo o exercício, entre outras. }\end{array}$ \\
\hline Espera & $\begin{array}{l}\text { Incluímos diferentes tipos de espera. Nessa categoria, incluímos subcategorias de ações } \\
\text { que remetem à ação em que o professor está esperando, ora que seus alunos copiem o } \\
\text { conteúdo do quadro, ora que eles resolvam os exercícios ou que fiquem quietos, entre } \\
\text { outras. }\end{array}$ \\
\hline Escreve & $\begin{array}{l}\text { Inserimos os processos de escrita. Nela acomodamos as subcategorias de ações em que o } \\
\text { professor escreve conteúdo ou exercício no quadro; ação em que o professor escreve no }\end{array}$ \\
\hline
\end{tabular}


quadro e interrompe a escrita para chamar a atenção de aluno ou alunos; ação em que o professor escreve no quadro e interrompe com a finalidade de conversar com alguém (sem relação com o conteúdo).

Fonte: Adaptado de Andrade (2016) e Carvalho (2019).

Nosso primeiro movimento analítico foi temporizar todas as ações encontradas na primeira aula - primeira situação de microensino - do licenciando, antes da intervenção do professor formador. No segundo movimento de análise, realizamos a categorização e temporizamos as ações da segunda aula - segunda situação de microensino -, após a intervenção. Com os dados levantados do primeiro e do segundo microensino elaboramos um gráfico para a comparação, que apresentaremos na seção de análise dos dados.

Após identificarmos duas categorias presentes nas ações do licenciando (categoria Explica e categoria Espera), iniciamos outro processo, considerando os procedimentos da Análise Textual Discursiva (ATD) (MORAES; GALIAZZI, 2011), em que os autores destacam que a retomada de todo o processo analítico na busca de novas e/ou outras evidências, a emergência de detalhes ou destaques antes não observados, tornando o processo cíclico e evolutivo, 'como se mergulhássemos' em busca de um aprofundamento na análise, conduziunos às subcategorias emergentes, que foram nominadas utilizando o verbo de ação no gerúndio e codificadas a partir das quatro categorias a priori apresentadas por Andrade (2016).

Justificamos a inexistência das categorias Burocrático-administrativa e Escreve, por se tratar de situações de microensino simuladas em aulas não ocorridas em um ambiente escolar 'real' e, sim, na instituição formadora, ou seja, nas salas de aula da própria Universidade, as quais foram ministradas para os colegas de turma, fato que não exigia chamadas de alunos ou recados pedagógicos (ação Burocrático-administrativa). No que diz respeito à escrita, o estudante analisado não fez esta opção pedagógica, pois planejou seus microensinos somente com a apresentação de slides por meio de um projetor, trabalhando com textos de apoio impressos e materiais experimentais.

Cabe destacar que a escolha dos nomes das subcategorias ocorreu por meio de interpretações das falas e das observações das gravações. Apresentaremos fragmentos das transcrições analisadas, todavia sugerimos ao leitor que acesse Carvalho (2019) para a verificação da transcrição completa, o que pode minimizar discordância da lógica interpretativa entre o fragmento escolhido e a subcategoria compreendida. Indicamos tal possibilidade, pois apenas a leitura do fragmento, sem o contexto, pode desalinhar o conjunto de ações que deu origem à subcategoria. 
A fim de elucidar os comentários do parágrafo anterior, trazemos dois exemplos para a categoria Explica. Exemplo 1: quando estavam direcionadas para a organização da aula "Lembrando que não é simplesmente você comer esse agradinho, tem que analisar ele, certo? Sentir o cheiro dele, sentir o sabor dele [...]" - criamos a subcategoria 1a, que denominamos 'Organizando o desenvolvimento da aula' e recebe o número 1, por ser a primeira ação a ser evidenciada, e a letra a, por ser a primeira forma de 'organização' proposta por ele. Exemplo 2: quando suas falas traziam diversos questionamentos, objetivando gerar reflexão ou interação ‘com' e 'entre' os alunos “Qual o tipo de ligação eu tenho entre os carbonos?” e "E aí, entraram num consenso?" - elaboramos neste caso duas subcategorias: 'Questionando para gerar reflexão' e 'Questionando para gerar interação', que foram codificadas por 3a e 3c, respectivamente.

Nos Quadros 3 e 4, relacionamos todas as subcategorias da categoria Explica e da categoria Espera, que, posteriormente, retomaremos com diversos movimentos argumentativos para justificar as interpretações que culminaram na evidenciação das subcategorias. Como pode ser observado, o número 1 indica a ação 'organizando', mas como só tivemos uma forma de organização temos o 1 acompanhado da letra 'a', o que vale para a ação 'definindo'. No caso da ação 'questionando' tivemos seis formas de questionamentos evidenciadas, por isso o número 3 segue acompanhado das letras de 'a' até 'f'. A mesma codificação e lógica segue para as demais. Considerando os numerais e as letras que diferenciam ações especificamente, isto é, em suas singularidades, temos para a categoria Explica 14 subcategorias (Quadro 3).

Quadro 3 - Subcategorias da categoria Explica

\begin{tabular}{|c|c|}
\hline Codificação & Subcategorias da categoria Explica \\
\hline $1 \mathrm{a}$ & Organizando o desenvolvimento da aula. \\
\hline $2 \mathrm{a}$ & Definindo o conceito. \\
\hline $3 \mathrm{a}$ & Questionando para o desenvolvimento da aula. \\
\hline $3 \mathrm{~b}$ & Questionando para gerar reflexão. \\
\hline $3 \mathrm{c}$ & Questionando para gerar interação. \\
\hline $3 \mathrm{~d}$ & Questionando para introduzir conceito. \\
\hline $3 \mathrm{e}$ & Questionando para explorar informações do aluno. \\
\hline $3 \mathrm{f}$ & Questionando de maneira retórica. \\
\hline $4 \mathrm{a}$ & Chamando atenção para desenvolvimento da aula. \\
\hline $4 \mathrm{~b}$ & Chamando atenção de conceitos anteriores. \\
\hline $5 \mathrm{a}$ & Relacionando texto com cotidiano/conceitos. \\
\hline $6 \mathrm{a}$ & Direcionando a atividade de forma parcial para o aluno. \\
\hline $6 \mathrm{~b}$ & Direcionando a atividade de forma total para o aluno. \\
\hline $7 \mathrm{a}$ & Outros tipos. \\
\hline
\end{tabular}

Fonte: Os autores. 
No Quadro 4, como já indicado, temos as subcategorias da categoria Espera, representadas por três verbos de ações, distribuídos em 8 subcategorias.

Quadro 4 - Subcategorias da categoria Espera

\begin{tabular}{|l|l|}
\hline Codificação & \multicolumn{1}{c|}{ Subcategorias da categoria Espera } \\
\hline $1 \mathrm{a}$ & Direcionando de forma total o desenvolvimento dos exercícios para o aluno. \\
\hline $1 \mathrm{~b}$ & Direcionando o desenvolvimento do exercício para os alunos. \\
\hline $2 \mathrm{a}$ & Argumentando para o aluno, de forma expositiva, conceitos estudados anteriormente. \\
\hline $3 \mathrm{a}$ & Orientando a pergunta para o aluno para o desenvolvimento dos exercícios. \\
\hline $3 \mathrm{~b}$ & Orientando a pergunta do aluno para a turma. \\
\hline $3 \mathrm{c}$ & Orientando a pergunta e direcionando a resposta. \\
\hline $3 \mathrm{~d}$ & Orientando o aluno no desenvolvimento do exercício. \\
\hline $3 \mathrm{e}$ & Orientando a pergunta para retomar o conceito. \\
\hline
\end{tabular}

Fonte: Os autores.

No Quadro 5, descrevemos todas as subcategorias encontradas na categoria Explica do primeiro microensino. Pode-se observar que ele foi subdividido em quatro colunas, sendo que na primeira coluna encontram-se os códigos de identificação e a quantidade de fragmentos enquadrados em cada subcategoria emergente. O código 1EX1a15 (primeira linha do Quadro 5), 1 refere-se à primeira situação de microensino, EX à categoria Explica e 1a ao código da subcategoria. O número 15 indica a quantidade de vezes que esta subcategoria foi encontrada durante a análise dos dados desta situação em questão. Na segunda coluna incluímos as denominações das subcategorias emergentes; na terceira coluna, alguns exemplares de trechos da fala do licenciando que podem elucidar nossas escolhas e análises; na última coluna, a justificativa, de acordo com a interpretação realizada.

Nossa proposta, para a estrutura deste artigo, foi a de trazer, nesta seção, essas interpretações dos dados organizadas e que evidenciam detalhes de um movimento formativo, para que na próxima seção possamos apresentar os avanços e os desdobramentos do que ocorreu durante a atuação desse estudante no Estágio Supervisionado 2 da instituição em que estava inserido. Por isso, na continuidade, dedicaremos nossas inserções à descrição do Quadro 5 (primeira situação de microensino e a categoria Explica); do Quadro 6 (segunda situação de microensino e a categoria Explica); do Quadro 7 (primeira situação de microensino e a categoria Espera); do Quadro 8 (segunda situação de microensino e a categoria Espera).

Na Figura 2 trouxemos uma representação das etapas da categoria Explica e o tempo total de duração da categoria na aula simulada. Tempo em que o licenciando 'explica' o conteúdo proposto. 
Figura 2 - Esquema de sequência de análise da categoria Explica

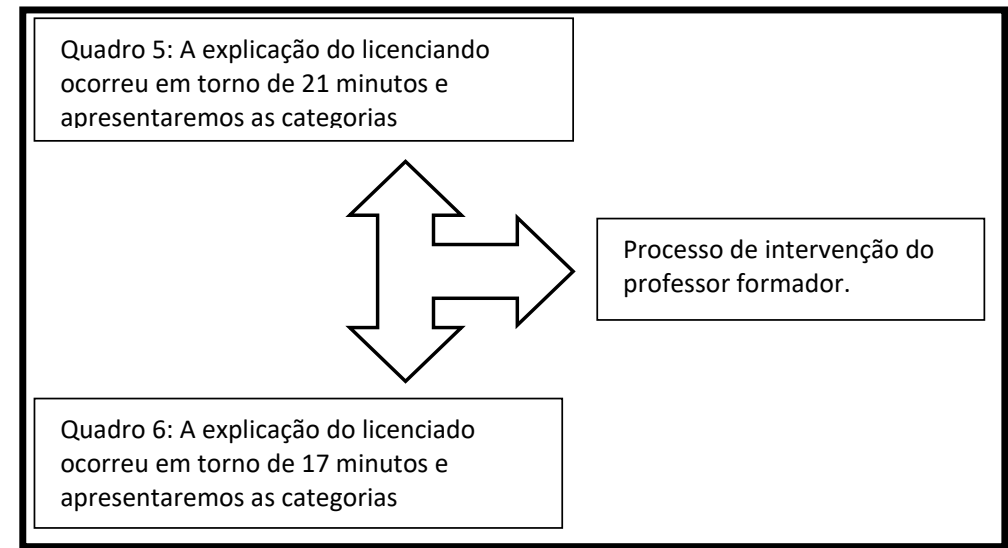

Fonte: Os autores.

Segue o Quadro 5, conforme descrito.

Quadro 5 - Descritivo analítico da categoria Explica do Microensino 1

\begin{tabular}{|c|c|c|c|}
\hline Codificação & Subcategorias & Exemplares de trechos das falas & Justificativas \\
\hline 1EX1a15 & $\begin{array}{l}\text { Organizando o } \\
\text { desenvolvimento } \\
\text { da aula. }\end{array}$ & $\begin{array}{l}\text { - Hoje nós vamos continuar a nossa } \\
\text { aula de Química Orgânica, beleza? } \\
\text { Lembrando que já vimos várias } \\
\text { funções orgânicas até ácidos } \\
\text { carboxílicos. Certo? } \\
\text { - Lembrando que não é simplesmente } \\
\text { você comer esse agradinho, tem que } \\
\text { analisar ele, certo? Sentir o cheiro } \\
\text { dele, sentir o sabor dele, certo? }\end{array}$ & $\begin{array}{l}\text { Fragmentos em que o } \\
\text { licenciando explica } \\
\text { instruções para o } \\
\text { desenvolvimento da aula. } \\
{ }^{2} \text { (Direcionando a } \\
\text { atividade). }\end{array}$ \\
\hline $1 \mathrm{EX} 2 \mathrm{a} 10$ & $\begin{array}{l}\text { Definindo o } \\
\text { conceito. }\end{array}$ & $\begin{array}{l}\text { - Então o Fischer obtém o éster por } \\
\text { esterificação... onde a gente pega um } \\
\text { álcool primário, um ácido carboxílico } \\
\text { e temos então o éster. } \\
\text { - O éster de cadeia curta são os } \\
\text { principais que têm o flavour, né... o } \\
\text { cheiro e o gosto. }\end{array}$ & $\begin{array}{l}\text { Exposição direta da } \\
\text { explicação e definição dos } \\
\text { conceitos. O professor } \\
\text { diretamente define conceito } \\
\text { na forma expositiva } \\
\text { tradicional, o aluno copia e } \\
\text { decora de forma passiva. }\end{array}$ \\
\hline $1 \mathrm{EX} 3 \mathrm{a} 09$ & $\begin{array}{l}\text { Questionando } \\
\text { para o } \\
\text { desenvolvimento } \\
\text { da aula. }\end{array}$ & $\begin{array}{l}\text { - Qual sabor que você acha que é? } \\
\text { - E aí, todo mundo anotou? } \\
\text { - [...] então alguém gostaria de ler o } \\
\text { primeiro parágrafo? }\end{array}$ & $\begin{array}{l}\text { Perguntas que possibilitam } \\
\text { o desenvolvimento da aula. }\end{array}$ \\
\hline 1EX3b09 & $\begin{array}{l}\text { Questionando } \\
\text { para gerar } \\
\text { reflexão. }\end{array}$ & $\begin{array}{l}\text { - Qual o tipo de ligação eu tenho } \\
\text { entre os carbonos? } \\
\text { - Mas o aromatizante não é o cheiro? }\end{array}$ & $\begin{array}{l}\text { Perguntas que levam os } \\
\text { alunos a refletirem acerca } \\
\text { do tema da aula. }\end{array}$ \\
\hline $1 \mathrm{EX} 3 \mathrm{c} 11$ & $\begin{array}{l}\text { Questionando } \\
\text { para gerar } \\
\text { interação. }\end{array}$ & $\begin{array}{l}\text { - Tá certo, gente? } \\
\text { - E aí, entraram num consenso? } \\
\text { Alguma hipótese? }\end{array}$ & $\begin{array}{l}\text { Perguntas para gerar } \\
\text { interação professor- } \\
\text {-aluno e aluno-aluno. }\end{array}$ \\
\hline $1 \mathrm{EX} 3 \mathrm{~d} 02$ & $\begin{array}{l}\text { Questionando } \\
\text { para introduzir } \\
\text { conceito. }\end{array}$ & $\begin{array}{l}\text { - Então beleza. Mas e aí, professora, o } \\
\text { que que eu faço, como eu identifico um } \\
\text { Éster? } \\
\text { - Como é que eu faço pra nomear e } \\
\text { identificar a cadeia? } \\
\text { - Qual que é o prefixo? }\end{array}$ & $\begin{array}{l}\text { Perguntas para ajudar na } \\
\text { lógica de definição do } \\
\text { conceito. }\end{array}$ \\
\hline
\end{tabular}

\footnotetext{
${ }^{2}$ Entre parênteses, trazemos algumas explicações para situar algumas justificativas relacionadas aos exemplares selecionados das falas.
} 


\begin{tabular}{|c|c|c|c|}
\hline $1 \mathrm{EX} 3 \mathrm{e} 02$ & $\begin{array}{l}\text { Questionando } \\
\text { para explorar } \\
\text { informações do } \\
\text { aluno. }\end{array}$ & $\begin{array}{l}\text { - Que sabor que você sentiu? } \\
\text { - É? Lewis, que sabor que você acha } \\
\text { que é? }\end{array}$ & $\begin{array}{l}\text { Durante a explicação o } \\
\text { licenciando faz perguntas } \\
\text { que buscam percepções dos } \\
\text { alunos referentes a um } \\
\text { determinado } \\
\text { assunto/conceito. }\end{array}$ \\
\hline 1EX3f11 & $\begin{array}{l}\text { Questionando de } \\
\text { maneira retórica. }\end{array}$ & $\begin{array}{l}\text { - A nomenclatura... o prefixo do nome } \\
\text { dos ácidos carboxílicos é ácido... o } \\
\text { que que é o prefixo mesmo? É a } \\
\text { quantidade de carbono que eu tenho } \\
\text { na cadeia principal... certo... um } \\
\text { carbono é met, dois carbonos é et... o } \\
\text { infixo é o tipo de ligação que eu tenho } \\
\text { entre dois carbonos, simples an, dupla } \\
\text { en, tripla é in. } \\
\text { - Cadeia principal... carbono com } \\
\text { dupla } O \text {, certo eu tenho quantos } \\
\text { carbonos aqui? }\end{array}$ & $\begin{array}{l}\text { Perguntas que direcionam a } \\
\text { resposta para o aluno. }\end{array}$ \\
\hline $1 \mathrm{EX} 4 \mathrm{a} 01$ & $\begin{array}{l}\text { Chamando } \\
\text { atenção para } \\
\text { desenvolvimento } \\
\text { da aula. }\end{array}$ & $\begin{array}{l}\text { - Agora prometo que é a última... vai } \\
\text { lá. }\end{array}$ & $\begin{array}{l}\text { Comentários para auxiliar a } \\
\text { dinâmica da aula e para } \\
\text { manter a atenção dos } \\
\text { alunos. }\end{array}$ \\
\hline 1EX4b02 & $\begin{array}{l}\text { Chamando } \\
\text { atenção de } \\
\text { conceitos } \\
\text { anteriores. }\end{array}$ & $\begin{array}{l}\text { - Já vimos isso... ele vai possuir o } \\
\text { grupo carboxila [...] } \\
\text { - Poxa gente... vamos lá... vamos } \\
\text { relembrar... relembrar é viver. } \\
\text { Tetravalente é porque ele vai fazer } \\
\text { quatro ligaçôes, lembram? }\end{array}$ & $\begin{array}{l}\text { Falas para auxiliar a } \\
\text { dinâmica da aula, } \\
\text { relembrando conceitos } \\
\text { anteriores. }\end{array}$ \\
\hline $1 \mathrm{EX} 5 a 08$ & $\begin{array}{l}\text { Relacionando } \\
\text { texto / cotidiano / } \\
\text { conceitos. }\end{array}$ & $\begin{array}{l}\text { - Como, por exemplo, nós temos aqui } \\
\text { as frutas e também temos aqui o vinho, } \\
\text { por exemplo, que é o epitanoato de } \\
\text { etila e algumas flores como a rosa, } \\
\text { que é o manilato de etila... é... pinha, } \\
\text { que é o ectanoato de etila, et cetera. } \\
\text { - Sim, esse... e... ah! Quando você está } \\
\text { com fome e você sente aquele cheiro } \\
\text { de comida de vovó assim, a boca } \\
\text { enche de água... então... é ligado, né? } \\
\text { O olfato com o sabor. }\end{array}$ & $\begin{array}{l}\text { Momentos em que assuntos } \\
\text { do cotidiano são } \\
\text { apresentados e } \\
\text { relacionados com o } \\
\text { conceito estudado. }\end{array}$ \\
\hline 1EX6a11 & $\begin{array}{l}\text { Direcionando a } \\
\text { atividade de } \\
\text { forma parcial para } \\
\text { o aluno. }\end{array}$ & $\begin{array}{l}\text { - E o sufixo que é utilizado no ácido } \\
\text { carboxílico é o oico... então... com a } \\
\text { terminação oico... então, vamos lá } \\
\text { gente, nomeando a nossa estruturinha } \\
\text { aqui... identifiquei que tem C } C \text { dupla } O \\
\text { e OH, então é um ácido carboxílico... } \\
\text { e o prefixo? Tem dois carbonos... } \\
\text { - E a terminação oico, ou seja, ácido } \\
\text { metanoico. }\end{array}$ & $\begin{array}{l}\text { Momento em que, durante } \\
\text { a explicação de conceitos e } \\
\text { exemplos, o futuro } \\
\text { professor direciona o } \\
\text { raciocínio do aluno para } \\
\text { resolução dos exercícios ou } \\
\text { compreensão do conceito. }\end{array}$ \\
\hline $1 \mathrm{EX} 7 \mathrm{a} 12$ & Outros tipos. & $\begin{array}{l}\text { - Certo! } \\
\text { - Hum... }\end{array}$ & $\begin{array}{l}\text { Fragmentos a partir dos } \\
\text { quais não foi possível } \\
\text { montar uma categoria. }\end{array}$ \\
\hline
\end{tabular}

Fonte: Carvalho (2019, p.58).

Os mesmos movimentos, analítico e de codificação, utilizados para a situação de Microensino 1 foram repetidos para a segunda. No Quadro 6, apresentamos todas as subcategorias que emergiram para a categoria Explica para o Microensino 2. 
A estrutura das colunas segue a mesma descrição indicada para o Quadro 5. Cabe salientar que há um pequeno ajuste na codificação: pelo fato de ser a segunda situação de microensino, os códigos possuem inicialmente o número 2. Sendo assim, 2EX1a09, 2 refere-se ao segundo microensino, EX à categoria Explica, 1a ao código da subcategoria, 09 o total de subcategoria encontrada.

Quadro 6 - Descritivo analítico da categoria Explica do Microensino 2

\begin{tabular}{|c|c|c|c|}
\hline Codificação & Subcategorias & Exemplares de trechos das falas & Justificativas \\
\hline 2EX1a09 & $\begin{array}{l}\text { Organizando o } \\
\text { desenvolvimento } \\
\text { da aula. }\end{array}$ & $\begin{array}{l}\text { - Boa noite, pessoal, hoje vamos } \\
\text { começar a aula de uma forma } \\
\text { diferente, eu trouxe aqui três } \\
\text { substâncias, na qual vocês devem } \\
\text { descobrir o que é, tudo bem? A partir } \\
\text { do olfato! }\end{array}$ & $\begin{array}{l}\text { Fragmentos em que o } \\
\text { licenciando passa instruções } \\
\text { para o desenvolvimento da } \\
\text { aula. (Direcionando a } \\
\text { atividade). }\end{array}$ \\
\hline 2EX2a01 & $\begin{array}{l}\text { Definindo o } \\
\text { conceito. }\end{array}$ & $\begin{array}{l}\text { - Então concluímos que cada planta } \\
\text { possui sua característica e cada uma } \\
\text { possui as suas propriedades. }\end{array}$ & $\begin{array}{l}\text { Exposição direta da } \\
\text { explicação e definição dos } \\
\text { conceitos. }\end{array}$ \\
\hline 2EX3a01 & $\begin{array}{l}\text { Questionando } \\
\text { para o } \\
\text { desenvolvimento } \\
\text { da aula. }\end{array}$ & $\begin{array}{l}\text {-Olhando essas estruturas aqui, o que } \\
\text { tem a ver que vocês conhecem? }\end{array}$ & $\begin{array}{l}\text { Perguntas que possibilitam o } \\
\text { desenvolvimento da aula. }\end{array}$ \\
\hline 2EX3b09 & $\begin{array}{l}\text { Questionando } \\
\text { para gerar } \\
\text { reflexão. }\end{array}$ & $\begin{array}{l}\text { - Mas se, ao invés de usar cravo... } \\
\text { você usar pimenta do reino? } \\
\text { - Qual é o critério que você usa, pra } \\
\text { falar que não é doce e o outro é feito } \\
\text { de sal? }\end{array}$ & $\begin{array}{l}\text { Perguntas que fazem o aluno } \\
\text { ou a turma refletir acerca do } \\
\text { tema da aula. }\end{array}$ \\
\hline $2 \mathrm{EX} 3 \mathrm{c} 01$ & $\begin{array}{l}\text { Questionando } \\
\text { para gerar } \\
\text { interação. }\end{array}$ & $\begin{array}{l}\text { - Só para concluir, que vocês acham } \\
\text { que é? }\end{array}$ & $\begin{array}{l}\text { Perguntas para gerar interação } \\
\text { professor-aluno e aluno-aluno. }\end{array}$ \\
\hline 2EX3e11 & $\begin{array}{l}\text { Questionando } \\
\text { para explorar } \\
\text { informações do } \\
\text { aluno. }\end{array}$ & $\begin{array}{l}\text { - Você saberia dizer que substância é } \\
\text { essa? } \\
\text { - Certo, todo mundo conseguiu } \\
\text { relacionar com o conteúdo? }\end{array}$ & $\begin{array}{l}\text { Perguntas que buscam } \\
\text { percepções dos alunos } \\
\text { referentes a um determinado } \\
\text { assunto/conceito. }\end{array}$ \\
\hline 2EX4a01 & $\begin{array}{l}\text { Chamando } \\
\text { atenção para } \\
\text { desenvolvimento } \\
\text { da aula. }\end{array}$ & $\begin{array}{l}\text { - Lembrando que estamos terminando } \\
\text { o terceiro ano do ensino médio. }\end{array}$ & $\begin{array}{l}\text { Frases para auxiliar a } \\
\text { dinâmica da aula e manter a } \\
\text { atenção dos alunos. }\end{array}$ \\
\hline 2EX5a11 & $\begin{array}{l}\text { Relacionando } \\
\text { texto / cotidiano / } \\
\text { conceitos. }\end{array}$ & $\begin{array}{l}\text { - Bom, outros motivos para serem } \\
\text { taxadas como bruxas usavam muitas } \\
\text { substâncias alucinógenas, e então } \\
\text { falava para os outros que elas voavam } \\
\text { nas vassouras, o que não acontecia, a } \\
\text { não ser na cabeça da pessoa. } \\
\text { - Enfim, especiarias a mesma coisa } \\
\text { que condimentos e cada um tem uma } \\
\text { aplicação na indústria alimentícia e na } \\
\text { indústria de medicamento. }\end{array}$ & $\begin{array}{l}\text { Momentos em que assuntos } \\
\text { do cotidiano são apresentados } \\
\text { e relacionados com o conceito } \\
\text { estudado. }\end{array}$ \\
\hline $1 \mathrm{EX} 7 \mathrm{a} 04$ & Outros tipos. & $\begin{array}{l}\text { - Pode! } \\
\text { - Gente, o vestibular está aí. }\end{array}$ & $\begin{array}{l}\text { Fragmentos a partir dos quais } \\
\text { não foi possível montar uma } \\
\text { categoria. }\end{array}$ \\
\hline
\end{tabular}

Fonte: Carvalho (2019, p.64). 
A evidenciação das ações ocorreu durante o desenvolvimento da explicação, conforme o licenciando explicitava suas ideias para explicar o conteúdo. Para a situação de Microensino 1 percebemos alunos passivos e receptores de conhecimento, centralizadas nas ações do licenciando. Para a situação de Microensino 2 ficaram perceptíveis alguns indícios de construção de conhecimento por meio de perguntas para identificar o que o aluno sabia e a indução para que ele construísse o próprio conhecimento.

Da mesma forma que criamos as subcategorias para categoria Explica, realizamos o procedimento para elaborar subcategorias para a categoria Espera. Observamos os momentos em que o licenciando esperava por uma manifestação dos alunos. No Quadro 7, trazemos todas as subcategorias encontradas para a categoria Espera para a situação Microensino 1. A estrutura do quadro segue os mesmos parâmetros já indicados e a codificação fica alterada somente para as letras que representam a categoria, deixando de ser EX (relacionado à categoria Explica) e passando a ser ES (relacionado à categoria Espera).

A seguir, na Figura 3, representamos o tempo total de duração da categoria na aula simulada, ou seja, tempo em que o professor 'espera' os alunos se manifestarem.

Figura 3 - Esquema de sequência de análise da categoria Espera

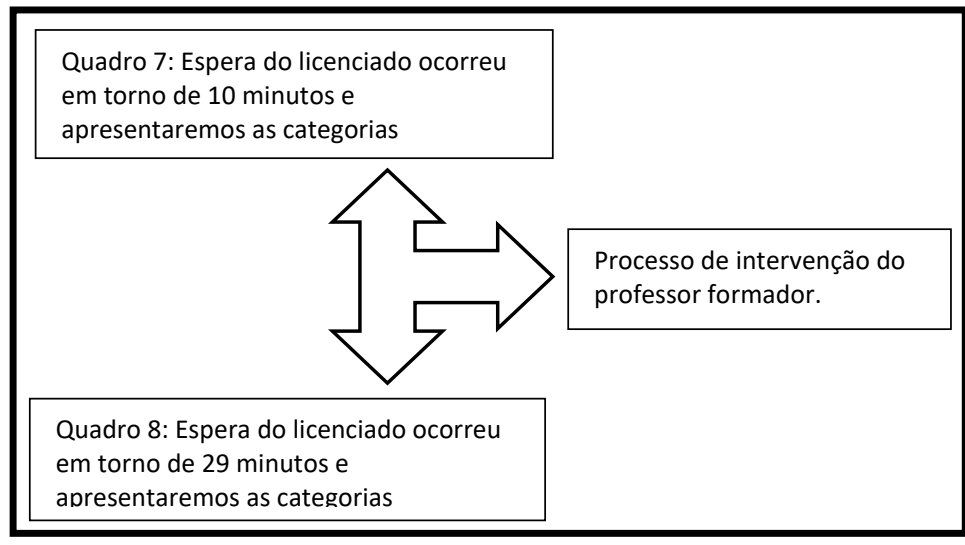

Fonte: Os autores.

Segue o Quadro 7, conforme descrito.

Quadro 7 - Descritivo analítico da categoria Espera do Microensino 1

\begin{tabular}{|c|l|l|l|}
\hline Codificação & \multicolumn{1}{|c|}{ Subcategorias } & $\begin{array}{l}\text { Exemplares de trechos das } \\
\text { falas }\end{array}$ & \multicolumn{1}{c|}{ Justificativas } \\
\hline \multirow{2}{*}{$1 \mathrm{ES} 1 \mathrm{a} 03$} & $\begin{array}{l}\text { Direcionando de } \\
\text { forma total o } \\
\text { desenvolvimento } \\
\text { dos exercícios para } \\
\text { o aluno. }\end{array}$ & $\begin{array}{l}- \text { Tem que completar com } \\
\text { hidrogênios! } \\
- \text { Primeiro vamos localizar } \\
\text { a cadeia principal. }\end{array}$ & $\begin{array}{l}\text { Fragmento em que o licenciando } \\
\text { espera as ações do aluno, o } \\
\text { licenciando fica ao lado da mesa } \\
\text { apenas dando dicas e deixa os } \\
\text { alunos desenvolverem o } \\
\text { exercício. }\end{array}$ \\
\hline $1 \mathrm{ES} 2 \mathrm{a} 06$ & $\begin{array}{l}\text { Argumentando para } \\
\text { o aluno de forma } \\
\text { expositiva conceitos }\end{array}$ & $\begin{array}{l}- \text { Nosso carbono é } \\
\text { tetravalente... todos os } \\
\text { nossos carbonos... e agora... }\end{array}$ & $\begin{array}{l}\text { Fragmentos em que licenciando } \\
\text { apresenta um determinado } \\
\text { conceito de forma expositiva. }\end{array}$ \\
\hline
\end{tabular}




\begin{tabular}{|c|c|c|c|}
\hline & $\begin{array}{l}\text { anteriores } \\
\text { estudados. }\end{array}$ & $\begin{array}{l}\text { - Dupla } O \text { não... dupla } O \ldots . . . \\
\text { O e o radical. }\end{array}$ & \\
\hline 1ES3a05 & $\begin{array}{l}\text { Orientando a } \\
\text { pergunta para o } \\
\text { aluno para o } \\
\text { desenvolvimento } \\
\text { dos exercícios. }\end{array}$ & $\begin{array}{l}\text { - Que sabor você sentiu? } \\
\text { - Pode! Por onde que } \\
\text { começa? }\end{array}$ & $\begin{array}{l}\text { Fragmentos em que a professora } \\
\text { realiza a pergunta para o } \\
\text { desenvolvimento do exercício. }\end{array}$ \\
\hline 1ES3b02 & $\begin{array}{l}\text { Orientando a } \\
\text { pergunta do aluno } \\
\text { para a turma. }\end{array}$ & $\begin{array}{l}\text { - Aluno: É assim } \\
\text { professora? } \\
\text { - Licl: Tá certo, gente? }\end{array}$ & $\begin{array}{l}\text { Fragmento em que o licenciando } \\
\text { transfere a pergunta para os } \\
\text { alunos forçando a participação de } \\
\text { todos. }\end{array}$ \\
\hline $1 \mathrm{ES} 3 \mathrm{c} 01$ & $\begin{array}{l}\text { Orientando a } \\
\text { pergunta e direciona } \\
\text { a resposta. }\end{array}$ & $\begin{array}{l}\text { - Abacaxi é o quê? } \\
\text { Butanoato de etila... gente, } \\
\text { pode ajudar o coleguinha. }\end{array}$ & $\begin{array}{l}\text { Fragmentos em que o licenciando } \\
\text { realiza uma pergunta e na } \\
\text { sequência responde sem dar } \\
\text { tempo para os alunos } \\
\text { responderem. }\end{array}$ \\
\hline 1ES3d04 & $\begin{array}{l}\text { Orientando o aluno } \\
\text { no desenvolvimento } \\
\text { do exercício }\end{array}$ & $\begin{array}{l}\text { - Isso... e o meu radical? } \\
\text { - Etila são quantos } \\
\text { carbonos? }\end{array}$ & $\begin{array}{l}\text { Fragmento em que o licenciando } \\
\text { orienta a resolução do exercício. }\end{array}$ \\
\hline
\end{tabular}

Fonte: Carvalho (2019, p.60).

Finalizando este movimento interpretativo-analítico-organizacional, trazemos no Quadro 8 as subcategorias representativas do Microensino 2 relativas à categoria Espera, estabelecida a priori. A estrutura do quadro segue as mesmas indicações e descrições, sofrendo unicamente a alteração relativa ao número inicial, que agora, em relação ao Quadro 7, deixa de ser 1 e passa a ser o número 2.

Quadro 8 - Descritivo analítico da categoria Espera do Microensino 2

\begin{tabular}{|c|c|c|c|}
\hline Codificação & Subcategorias & $\begin{array}{l}\text { Exemplares de trechos das } \\
\text { falas }\end{array}$ & Justificativas \\
\hline 2ES1b05 & $\begin{array}{l}\text { Direcionando o } \\
\text { desenvolvimento do } \\
\text { exercício para os } \\
\text { alunos. }\end{array}$ & $\begin{array}{l}\text {-O, pessoal, o Al passou no } \\
\text { quadro a estrutura, agora } \\
\text { ajuda ele a identificar a } \\
\text { estrutura orgânica presente } \\
\text { ali. } \\
\text { - Bom, pessoal, ajudem a A9. } \\
\text { - Podem passar no quadro. }\end{array}$ & $\begin{array}{l}\text { Fragmentos em que o } \\
\text { licenciando induz a } \\
\text { participação dos alunos. }\end{array}$ \\
\hline 2ES3a02 & $\begin{array}{l}\text { Orientando a pergunta } \\
\text { para o aluno para o } \\
\text { desenvolvimento dos } \\
\text { exercícios. }\end{array}$ & $\begin{array}{l}\text { - Onde tem aldeído? } \\
\text { - Éter ou éster? }\end{array}$ & $\begin{array}{l}\text { Fragmentos em que o } \\
\text { licenciando realiza a } \\
\text { pergunta que desencadeia } \\
\text { o desenvolvimento do } \\
\text { exercício. }\end{array}$ \\
\hline 2ES3e01 & $\begin{array}{l}\text { Orientando a pergunta } \\
\text { para retomar o } \\
\text { conceito. }\end{array}$ & $\begin{array}{l}\text { - Qual é a diferença de Éter } \\
\text { para o Éster? }\end{array}$ & $\begin{array}{l}\text { Fragmentos que indicam a } \\
\text { retomada de conceitos } \\
\text { estudados anteriormente. }\end{array}$ \\
\hline
\end{tabular}

Fonte: Carvalho (2019, p.65).

Diante dessa apresentação que traz o registro e a organização de uma parte representativa dos dados, elaboramos para a próxima seção a descrição e diversos comentários a respeito do que compreendemos e do que podemos afirmar a respeito do que investigamos. 


\section{Resultados ANALíticos}

Antes de darmos início à apresentação de alguns outros resultados, esclarecemos que a coleta dos dados, sob os quais trabalhamos para a elaboração deste artigo, foi realizada em quatro etapas. Primeira: gravação e transcrição da situação Microensino 1, planejada e desenvolvida sem a intervenção do professor formador. Segunda: gravação e transcrição da intervenção do professor formador, em que ocorreu a observação do vídeo da proposta de Microensino 1, por meio do processo de autoscopia, ou seja, observação com comentários do professor formador e do graduando. Situação que nos remete à Figura 1 e pode ser relacionada aos destaques - Visionamento, Análise, Promoção de feedback, Síntese. Terceira: gravação e transcrição da situação Microensino 2, planejada a partir das orientações do professor formador e que, na Figura 1, podemos relacioná-la ao Reensino. Quarta: gravação e transcrição da entrevista final que ocorreu mediante a autoscopia da situação Microensino 2, em que professor e graduando realizavam seus comentários do vídeo proveniente da Terceira etapa.

Como já indicado em momento anterior, inicialmente alocamos as ações do estudante, considerando as categorias estabelecidas a priori, o que proporcionou a evidenciação de duas categorias de ações promovidas pelo estudante investigado: Explica e Escreve. A partir dessa constatação procuramos calcular o tempo de ocorrência de cada categoria nas situações de microensino. Essa quantificação do tempo possibilitou-nos a elaboração dos gráficos expostos na Figura 4.

Figura 4 - Representação percentual das categorias Explica e Espera

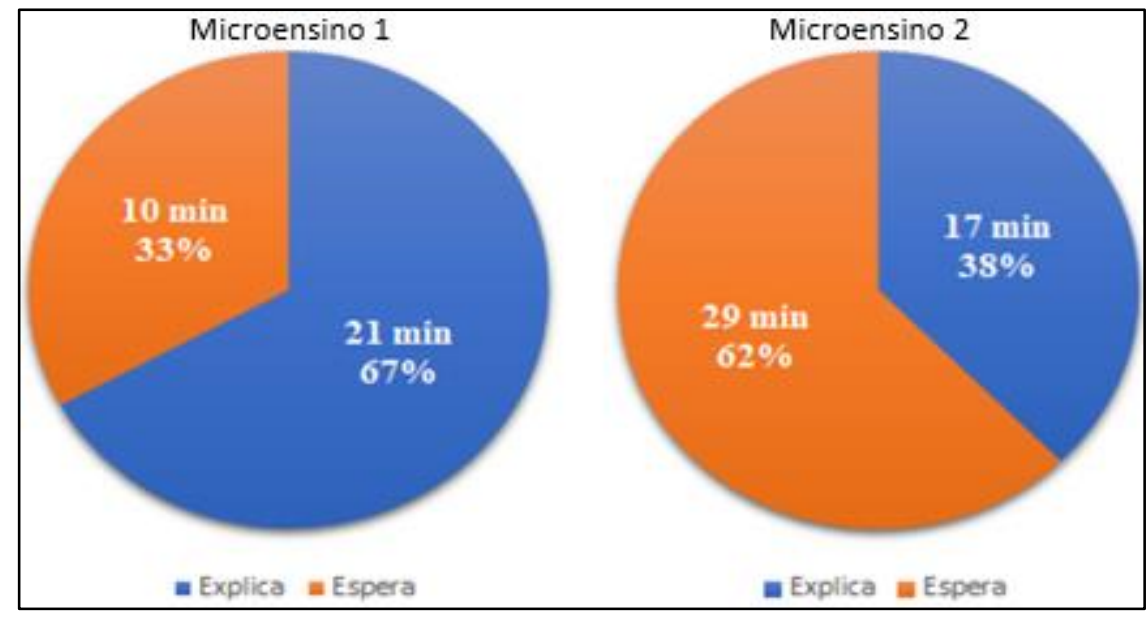

Fonte: Carvalho (2019, p. 67).

Observa-se na Figura 4 que as percentagens relativas às categorias Explica e Espera sofreram grande mudança, mesmo que tenhamos evidenciado somente essas duas. Para justificar tal alteração, retomamos os demais dados coletados, verificando na transcrição do 
processo de autoscopia os comentários do professor formador e do licenciando. A seguir, inserimos três excertos que corroboram com o que visualizamos nesses gráficos.
$\mathrm{PF}^{3}:$ (1) [...] então deixa eles pensarem um pouquinho mais nas perguntas que você faz.
PF: (2) [...] você nomeia o ácido embora faz a construção com os alunos.
PF: (3) tem que deixar um pouco mais solto isso, para ver o que vai dar, entendeu?

Interpretamos os fragmentos (1), (2) e (3) como possíveis falas que podem ter colaborado com essa variação do tempo destinado às ações que representa as categorias Explica e Espera. O futuro professor, no momento da explicação e na resolução de exercícios, realizava algumas perguntas e as respondia imediatamente, não deixando os alunos (participantes da aula simulada) responderem-nas. Mediante os comentários feitos pelo professor formador e a realização da autoscopia, o licenciando alterou sua proposta de microensino, partindo de uma situação de espera com $33 \%$ dos minutos da aula para $62 \%$, ou seja, na situação Microensino 2 houve um tempo de espera maior relacionado aos momentos em que o licenciando esperava os alunos resolverem os exercícios (sem sua intervenção), possibilitando a elaboração dos conhecimentos pelos alunos.

Por conseguinte, os minutos utilizados para explicações: $67 \%$ do tempo de aula no Microensino 1 para 38\% do tempo de aula no Microensino 2. As modificações numéricas nas categorias que levantamos por meio das interpretações das ações, podem, segundo nossa visão, ser um indicativo de mudança, pois percebemos, por meio dos vídeos, que no Microensino 1 os alunos estavam passivos, assumindo o papel de receptores à espera da transmissão do conhecimento do licenciando que se dedicava unicamente a explicar, o que ocupou $67 \%$ do seu tempo de aula. No decorrer da proposta de Microensino 2, ocorrida após a intervenção e realizada pelo professor formador, percebemos uma 'inversão' das modalidades Explica e Espera. Isto é, a ação 'espera' (do licenciando) torna-se mais presente e faz com que os alunos assumam um papel mais ativo na construção do próprio conhecimento, atuando de forma coletiva e compartilhada. Fica evidente a proposta de orientação assumida pelo licenciando o que demarcar $62 \%$ do tempo de sua aula - Microensino 2.

Todavia, aprofundamos nossas interpretações buscando pelas subcategorias que descreviam com detalhes as ações deste futuro professor. O resultado a que chegamos está exposto no Quadro 9 em três colunas, a fim de que possamos comparar as subcategorias encontradas na categoria Explica - Microensino 1 e Microensino 2.

\footnotetext{
${ }^{3} \mathrm{PF}$ - código de Professor Formador. 
Por isso, na primeira coluna colocamos o código de identificação da subcategoria; na segunda coluna, as denominações das subcategorias; e, na última coluna, as quantidades de vezes que as subcategorias foram evidenciadas no Microensino 1 e no Microensino 2.

Quadro 9 - Estudo verticalizado da categoria Explica

\begin{tabular}{|c|c|c|c|}
\hline \multirow[b]{2}{*}{ Codificação } & \multirow[b]{2}{*}{ Subcategorias da categoria Explica } & \multicolumn{2}{|c|}{$\begin{array}{l}\text { Quantidade de manifestações } \\
\text { relativa às subcategorias }\end{array}$} \\
\hline & & Microensino 1 & Microensino 2 \\
\hline $1 \mathrm{a}$ & Organizando o desenvolvimento da aula. & 16 & 9 \\
\hline $2 \mathrm{a}$ & Definindo o conceito. & 10 & 1 \\
\hline $3 \mathrm{a}$ & Questionando para o desenvolvimento da aula. & 12 & 1 \\
\hline $3 b$ & Questionando para gerar reflexão. & 9 & 8 \\
\hline $3 \mathrm{c}$ & Questionando para gerar interação. & 11 & 1 \\
\hline $3 d$ & Questionando para introduzir conceito. & 2 & 0 \\
\hline $3 e$ & Questionando para explorar informações do aluno. & 2 & 11 \\
\hline $3 f$ & Questionando de maneira retórica. & 10 & 0 \\
\hline $4 \mathrm{a}$ & Chamando atenção para desenvolvimento da aula. & 1 & 1 \\
\hline $4 \mathrm{~b}$ & Chamando atenção de conceitos anteriores. & 2 & 0 \\
\hline $5 \mathrm{a}$ & Relacionando texto com cotidiano/conceitos. & 5 & 10 \\
\hline $6 a$ & Direcionando a atividade de forma parcial para o aluno. & 11 & 0 \\
\hline $6 b$ & Direcionando a atividade de forma total para o aluno. & 0 & 2 \\
\hline
\end{tabular}

Fonte: Os autores.

Diante do Quadro 9, iniciamos uma verificação para tentarmos identificar as subcategorias em que houve maior variação numérica com relação às duas aulas. Algumas foram sombreadas como destaque e comentamos a seguir.

Após uma revisita aos dados encontramos as subcategorias 3e (Questionando para explorar informações do aluno), 2a (Definindo conceito) e 6a (Direcionando a atividade de forma parcial para o aluno), com alterações em sua evidenciação muito acentuadas, isto é, 2/11, 10/1, 11/0. Ao retomarmos a coleta de dados ocorrida na segunda etapa, verificamos diversos comentários do professor formador que podem justificar essas modificações. Relacionamos alguns na continuidade:

PF: (4) Assim, você tem que tentar de alguma maneira evidenciar qual é a dificuldade, porque se você vai dando a orientação, não tô falando que isso é errado nos exemplos ou nos exercícios, mas se você for dando a orientação você não consegue enxergar onde é a dificuldade deles, entendeu?

PF: (5) [...] deixar eles fazerem, pegar o nome ou vice e versa, tentar deixar eles fazerem tudo, para ver se eles conseguem construir a partir do que você trabalhou na aula, para ver se eles conseguem fazer sozinhos [...].

Os fragmentos (4) e (5), interpretamos como uma possível fala do professor formador, que justificaria a variação numérica nas subcategorias. Atribuímos às variações dos números 
das subcategorias indicativos de mudanças das ações, devido à interferência do professor formador.

No momento em que o professor formador indica ao licenciando para "Evidenciar qual é a dificuldade" e "para ver se eles conseguem construir", entendemos como o direcionamento em que PF solicita que o licenciando construa o aprendizado do aluno, por meio de questionamento, tentando investigar as dificuldades dele para que o discente participe ativamente na construção do seu próprio conhecimento e o professor assuma o papel de orientador na construção do conhecimento, assim como foi apresentado a eles durante as aulas da disciplina de Estágio Supervisionado 2, pautada no texto de Carvalho e Gil-Pérez (2011).

Observamos que a subcategoria $3 \mathrm{f}$ (Questionando de maneira retórica) não ocorreu no Microensino 2, fato que pode estar relacionado aos seguintes destaques:

\section{PF: (6) [...] tem algumas perguntas que você faz... que você responde já. \\ PF: (7) Você viu que você vai fazendo a pergunta e respondendo?}

Conforme nossas reflexões, encontramos nos fragmentos (6) e (7) indícios que poderiam sugerir uma mudança de ação, explicitada por meio da variação numérica nas subcategorias comparadas no Quadro 9. Entendemos que a subcategoria em que o professor pergunta e ele mesmo responde está vinculada ao modelo de transmissão de conhecimento. Após a intervenção houve a diminuição da subcategoria mencionada, à qual associamos uma possível tentativa de fazer o futuro professor diminuir a transmissão e deixar os alunos refletirem acerca da atividade proposta.

Como podemos constatar, retomando o Quadro 9, não foram somente esses os avanços ocorridos. Para os nossos destaques comentamos aqueles com maior variação, todavia poderíamos retomar esse quadro linha a linha e realizar uma leitura dessas alterações focadas nos diálogos ocorridos durante a realização do processo de autoscopia e de feedback promovido por PF.

Daremos atenção agora ao que aconteceu com as ações relacionadas à categoria Espera, organizadas no Quadro 10 com a mesma estrutura do anterior.

Quadro 10 - Estudo verticalizado da categoria Espera

\begin{tabular}{|c|c|c|c|}
\cline { 3 - 4 } \multicolumn{2}{c|}{} & \multicolumn{2}{c|}{$\begin{array}{c}\text { Quantidade de manifestações } \\
\text { relativa às subcategorias }\end{array}$} \\
\hline Codificação & Subcategorias da categoria Espera & Microensino 1 & Microensino 2 \\
\hline $1 \mathrm{a}$ & $\begin{array}{c}\text { Direcionando de forma total o desenvolvimento } \\
\text { dos exercícios para o aluno. }\end{array}$ & 3 & 0 \\
\hline $1 \mathrm{~b}$ & $\begin{array}{c}\text { Direcionando o desenvolvimento do exercício } \\
\text { para os alunos. }\end{array}$ & 0 & 5 \\
\hline
\end{tabular}




\begin{tabular}{|c|c|c|c|}
\hline $2 \mathrm{a}$ & $\begin{array}{c}\text { Argumentando para o aluno, de forma } \\
\text { expositiva, conceitos estudados anteriormente. }\end{array}$ & 6 & 0 \\
\hline $3 \mathrm{a}$ & $\begin{array}{c}\text { Orientando a pergunta para o aluno para o } \\
\text { desenvolvimento dos exercícios. }\end{array}$ & 5 & 2 \\
\hline $3 \mathrm{~b}$ & Orientando a pergunta do aluno para a turma. & 2 & 0 \\
\hline $3 \mathrm{c}$ & Orientando a pergunta e direcionando a \\
resposta. & 4 & 0 \\
\hline $3 \mathrm{~d}$ & Orientando o aluno no desenvolvimento do \\
exercício. & 0 & 1 \\
\hline $3 \mathrm{e}$ & Orientando a pergunta para retomar o conceito. & 0 & 0 \\
\hline
\end{tabular}

Fonte: Os autores.

Destacamos no Quadro 10 as subcategorias 1a (Direcionando de forma total o desenvolvimento dos exercícios para o aluno); 2a (Argumentando para o aluno, de forma expositiva, conceitos estudados anteriormente); 3a (Orientando a pergunta para o aluno para o desenvolvimento dos exercícios); 3d (Orientando o aluno no desenvolvimento do exercício) todas sombreadas. Diante das variações numéricas, procuramos nos dados coletados informações que justificassem tais alterações. Para esses casos evidenciamos diversos comentários, alguns deles selecionamos para inserção no artigo.

PF: (5) [...] deixar eles fazerem, pegar o nome ou vice e versa, tentar deixar eles fazerem tudo, para ver se eles conseguem construir a partir do que você trabalhou na aula, para ver se eles conseguem fazer sozinhos [...].

PF: (6) Você podia ter jogado para a turma, entende? Vamos ajudar ele aqui! Como que faz?

PF: (7) [...] eles irem ao quadro é eles discutirem entre eles primeiro, sem dar orientação nenhuma.

Neste conjunto de falas destacamos orientações do professor formador (“[...] deixar eles fazerem [...]”; “[...] para ver se eles conseguem construir [...]”), que nos remetem à compreensão de que o direcionamento proposto por ele foi incorporado no processo de Reensino do graduando, fazendo-o esperar por mais tempo antes de resolver os exercícios, dando aos alunos a oportunidade de se articularem nos grupos, para que cada grupo construísse o próprio conhecimento, coletivo neste caso. Fatos esses registrados na gravação e percebidos quando da retomada dos vídeos diante dos resultados a que chegamos.

Assim como comentamos após a apresentação do Quadro 9, neste momento também poderíamos retomar linha a linha o Quadro 10, comentando as alterações presentes em cada uma delas, no que diz respeito à quantificação das subcategorias e, paralelamente a isso, revisitar as gravações da segunda e da quarta etapa de coleta, destacando comentários e reflexões que justificassem essas variações. Contudo, cremos que o que foi descrito e interpretado sustenta os resultados a que chegamos, pois quando focamos nas ações do futuro professor e na fala (durante a intervenção) de PF, mesmo que de forma pontual na análise das 
aulas selecionadas para estudo, observamos os efeitos imediatos da intervenção. No momento oportuno ampliaremos nossa investigação para analisar os efeitos dos impactos das orientações e eficiência das ações e de suas modificações, considerando outros licenciandos da turma (formada por 6, neste caso), o que pode gerar novas subcategorias, incrementando os resultados.

\section{CONSIDERAÇões Finais}

Como indicado no resumo, nossa intenção com o desenvolvimento da investigação, cujos resultados trazemos neste artigo, foi analisar as ações de um licenciando em Química, quando cursava a disciplina de estágio supervisionado, em que sua preparação para a regência em sala de aula ocorreu por meio de situações de microensino, seguida de autoscopia.

Das quatro ações assumidas a priori - Burocrático-administrativa; Explica; Espera; Escreve - apresentadas por Andrade (2016), como resultado de uma pesquisa realizada com professores de Matemática em salas de aula regular, pudemos evidenciar duas delas - Explica; Espera - em uma situação simulada durante a disciplina de Estágio Supervisionado 2, que faz parte da grade curricular de um curso de Licenciatura em Química de uma Universidade Federal do estado do Paraná.

Orientados pelo "Esquema de integração de fase microensino e autoscopia" (representado na Figura 1), realizamos a tomada de dados, composta por quatro etapas. Ao final do processo investigativo pudemos concluir que, no ambiente simulado dentro do nosso contexto, duas categorias de ações estabelecidas a priori foram suprimidas, o que pode ser justificado pela perspectiva de simulação, ou seja, não era necessário um controle burocrático-administrativo, pois o graduando estava ministrando aula para os seus próprios colegas de sala e, também, não foi necessário o uso da escrita, em função dos recursos pedagógicos utilizados por ele: projetor de slides, textos impressos e atividade experimental.

Todavia, alguns avanços e particularidades em relação ao que nos apresentou Andrade (2016) puderam ser constatados. Entre eles relacionamos: as diversas subcategorias da categoria original Explica - Organizando o desenvolvimento da aula; Definindo o conceito; Questionando para o desenvolvimento da aula; Questionando para gerar reflexão; Questionando para gerar interação; Questionando para introduzir conceito; Questionando para explorar informações do aluno; Questionando de maneira retórica; Chamando atenção para o desenvolvimento da aula; Chamando atenção de conceitos anteriores; Relacionando texto com cotidiano/conceitos; Direcionando a atividade de forma parcial para o aluno; Direcionando a atividade de forma total para o aluno; e as diversas subcategorias da categoria original Espera 
- Direcionando de forma total o desenvolvimento dos exercícios para o aluno; Direcionando o desenvolvimento do exercício para os alunos; Argumentando para o aluno, de forma expositiva, conceitos estudados anteriormente; Orientando a pergunta para o aluno para o desenvolvimento dos exercícios; Orientando a pergunta do aluno para a turma; Orientando a pergunta e direcionando a resposta; Orientando o aluno no desenvolvimento do exercício; Orientando a pergunta para retomar o conceito. Ao acomodarmos essas subcategorias em quadros e identificarmos a frequência com que ocorreram, observamos variações da quantidade de ações relacionadas a cada uma dessas subcategorias entre as duas situações de microensino, o que nos leva a defender a relevância da realização das autoscopias e da intervenção do professor formador, justificando tais alterações/mudanças.

Tais evidenciações levam-nos a afirmar que processos formativos pautados em resultados de pesquisas, como neste caso, com situação simulada, o planejamento de microensinos, a utilização de autoscopias, a intervenção intencional do professor formador, colocando o licenciando em um estado reflexivo diante de referências teóricas selecionadas e que abordem essas práticas reflexivas, são situações a serem divulgadas e compartilhadas para que rompam com concepções de práticas não reflexivas, ampliando as perspectivas formativas dos futuros professores, as quais alterarão suas propostas de ensino, como pudemos constatar.

\section{REFERÊNCIAS}

ALARCÃO, Isabel. Formação reflexiva de professores: estratégias de supervisão. Porto: Porto Editora, 1996.

ANDRADE, Edelaine Cristina. Um estudo das ações de professores de matemática em sala de aula. 2016. 186f. Londrina: Tese (Doutorado em Ensino de Ciências e Educação Matemática) - Universidade Estadual de Londrina, Londrina, 2016.

ARRIGO, Viviane; LORENCINI JÚNIOR, Álvaro; BROIETTI, Fabiele Cristiane Dias. A autoscopia bifásica integrada ao microensino: uma estratégia de intervenção reflexiva na formação de professores de química. Revista Investigações em Ensino de Ciências, Porto Alegre, v. 22, n. 1, p. 1-22, 2017.

BEHRENS, Marilda Aparecida. A prática pedagógica e o desafio do paradigma emergente. Revista Brasileira de Estudos Pedagógicos, Brasília, v. 80, n. 196, p. 383-403, 1999.

CARVALHO, Anna Maria Pessoa; GIL-PÉREZ, Daniel. Formação de professores de ciências: tendências e inovações. 10. ed. São Paulo: Cortez, 2011.

CARVALHO, Wilson. Estudo da intervenção do professor formador nas ações dos licenciandos em Química. 2019. 162f. Londrina: Dissertação (Mestrado em Ensino de Ciências e Educação Matemática) - Universidade Estadual de Londrina, Londrina, 2019. 
FERNÁNDEZ, Maria Lorelei. Investigating how and what prospective teachers learn through microteaching lesson study. Teaching and Teacher Education, Miami, n. 26, p. 351-362, 2010.

FLICK, Uwe. Introdução à pesquisa qualitativa. 3. ed. Porto Alegre: Artmed, 2009.

LÜDKE, Menga; ANDRÉ, Marli Eliza Dalmazo Afonso. Pesquisa em educação: abordagens qualitativas. São Paulo: EPU, 1986.

MALDANER, Otavio Aloisio. A formação inicial e continuada de professores de Química: formando professores/pesquisadores. 3. ed. Ijuí: Unijuí, 2006.

MORAES, Roque; GALIAZZI, Maria do Carmo. Análise Textual Discursiva. Ijuí: Unijuí, 2011.

PIMENTA, Selma Garrido; LIMA, Maria Socorro Lucena. Estágio e docência. São Paulo: Cortez, 2017.

POZO, Juan Ignacio. Aprendizes e mestres: a nova cultura da aprendizagem. Porto Alegre: Artmed, 2002.

SACRISTÁN, Jose Gimeno; GOMEZ, Angel Inácio Pérez. Compreender e transformar o ensino. 4. ed. Porto Alegre: Artmed, 1998.

SADALLA, Ana Maria Falcão de Aragão; LAROCCA, Priscila. Autoscopia: um procedimento de pesquisa e de formação. Educação e Pesquisa, São Paulo, v. 30, n. 3, p. 419-433, 2004.

SCHÖN, Donald Alan. Educando o profissional reflexivo: um novo design para o ensino e a aprendizagem. Porto Alegre: Artmed, 2000.

TARDIF, Maurice. Saberes docentes e formação profissional. 17. ed. Petrópolis: Vozes, 2014.

Recebido em: 12 de julho de 2020.

Aprovado em: 21 de dezembro de 2020. 